\section{Nunca abandono la ficción para hacer documental. \\ Entrevista a Sergio Navarro}

\section{IVÁN PINTO VEAS}

$>$ Instituto de Comunicación e Imagen, Universidad de Chile. ivanpintoveas@gmail.com

Universidad de Valparaíso

Facultad de Arquitectura

Revista Márgenes

Espacio Arte Sociedad

Nunca abandono la ficción para hacer un documental.

Entrevista a Sergio Navarro

Agosto Diciembre 2020

Páginas 31 a 34

ISSN elec. 0719-4463

ISSN imp. 0718-4034

Recepción: abril 2019

Aceptación: octubre 2019

A Sergio Navarro lo conocí primero como profesor en la Universidad Arcis, hacia el año 1998, donde por años Sergio realizó clases. Sus clases buscaban darle espesor y densidad teórica al taller central de realización, en contraste con una línea muy fascinada con lo que en ese momento se nombraba como industria del cine.

Años más tarde Sergio fue una de las primeras personas que me abrió un espacio universitario cuando fundó la Escuela de Cine de la Universidad de Valparaíso. Con el pasar de los años, la curiosidad sobre sus trayectos y reflexiones acrecentaron mi interés por su obra cinematográfica como un "eslabón" entre el período de la Unidad Popular y la llamada Transición democrática con películas como Esperando a Godoy (1973), Vías paralelas (1975), De las armas y las letras (1987), Nostalgias del FarWest (1988), Caminito al cielo (1989).

Durante los años recientes Sergio sorprendió con una enorme capacidad teórica que en pocos años se tradujo en libros como Acerca del cine como medio expresivo (2011), Poética de las imágenes del cine (2014), La naturaleza ama ocultarse. El cine chileno de Raúl Ruiz (2019), La idea de pueblo en la encrucijada del cine latinoamericano en los años 60-70 (2019).

En esta entrevista, realizada especialmente para el presente dossier, realizamos un recorrido por sus reflexiones y procesos creativos en una trayectoria inquieta, marcada por su encuentro temprano con Raúl Ruiz.

Iván Pinto: Lo primero, quizás, remontándonos al principio es tratar de ordenar el tema de la salida de la EAC (Escuela de Artes de la Comunicación 1970-1978, UC). ¿Cuándo saliste? ¿Cuándo te fuiste a exilio? ¿Qué pasó ahí entre esos años?

Sergio Navarro: Es que la EAC para mí fue fundamental porque era una época en que no había mucho cine en Chile y el cine de ficción estaba recién naciendo. Estaban los casos de Littin y Ruíz iniciándose y estábamos muy sorprendidos por eso. La otra cosa que en la EAC nos golpeó mucho fue la Nouvelle vague, o sea conocimos a Godard y nos volamos con Godard, pero, también, veíamos Mi noche con Maud (Eric Rohmer, 1969) que fue un referente importante.

\section{¿De qué años estamos hablando?}

1972 y 1973, esa época. Digamos que había toda una experiencia cine club que era importante. Kerry Oñate nos enseñaba a ver cine y yo creo que fue fundamental eso.

¿Quiénes eran tus compañeros de generación?

Cristian Sánchez, David Vera-Meiggs, Ignacio Aliaga.

¿Esos eran tus yuntas, la gente con que hacías cosas?

Y lo han sido hasta ahora. 0 sea, con ellos yo me formé. Había más, pero se dispersaron.

¿Ustedes eran como los cabros más jóvenes? Porque en el fondo Littín o Chaskel, ya eran los que estaban metidos haciendo. Y ustedes estaban como una generación un poquito más joven que estaba por salir.

Bueno, hay una entrevista en Primer Plano, que me gustaría que vieras. Se hizo a este grupo con las mismas preguntas: ¿Qué son ustedes? ¿Qué éramos del cine chileno? Nos parece que a lo mejor pueden ser la promesa, era muy en esa onda. Y yo creo que ahí, nosotros empezamos a visibilizarnos como grupo. La cosa creo que iba super bien, dentro de una línea muy clara de desarrollo.

\section{¿Cómo la definirías?}

Mira, nosotros éramos gente de ficción. Todos nosotros queríamos hacer ficción, no queríamos hacer documental. En eso estábamos, reaccionando contra la experiencia documentalista que había en la Universidad de Chile, del Centro de Cine Experimental de la Universidad de Chile, y por eso nos acercamos más a Raúl Ruiz porque nos pareció que él podía hacer el nexo que nosotros andábamos buscando hacer.

Raúl Ruiz siempre nos pareció un tipo fascinante, desde el comienzo, y de alguna manera nos marcó mucho. Justamente, la película que más nos marcó fue El realismo socialista (1973) ¿Por qué? Porque él estaba haciendo la película cuando era profesor nuestro, entonces, nos invitaba a ver los rushes, nos invitó a ver cómo se estaba haciendo la banda sonora, y de repente descubrimos el plano de secuencia con Ruiz y dijimos: ¿qué es esto?, ¿una cámara fija? Y pasan tantas cosas. Y las voces empiezan a auscultarse unas con otras. ¿No fue eso deslumbrante? Que hubiese un cine diferente del que habíamos conocido en Chile. Ruiz casi no nos hablaba. 0 sea no era un tipo que nos dictara cátedra, sino que nos mostraba cosas, lo que estaba haciendo. Con esa actitud, digamos de develar un nuevo tipo de cine, nos conquistó a todos.

\section{¿Qué pasa ya en 1973 mismo, en tu caso personal?}

Bueno, en 1973 habíamos enganchado tanto con Raúl Ruiz que queríamos trabajar con él. Entonces, él nos invitó a una película en la cual estaba Cristian Sánchez, estaba yo y Rodrigo González que era otro compañero nuestro. Los tres íbamos a ser sus asistentes $y$, bueno, fascinados. Era como el paso lógico para que después nosotros nos desarrolláramos como cineastas.

¿No es ninguna de las películas consignadas de Ruiz en ese período?

No, pero esa película había sido pedida por el partido socialista e iba a tratar sobre la toma de fábrica, creo que era eso, no estoy seguro. Era un tema contingente, pero a la manera nues- 
tra. El trabajo él lo transformaba en otra cosa. La película iba a comenzar en septiembre, el 12 creo. Y nosotros estábamos preparándonos para comenzar a trabajar con él e incluso nos pagó. Una cuestión increíble, de repente yo veo un cheque. Estábamos todos contratados para poder iniciar la filmación. Y, realmente el día del golpe, fue más que un chancacazo, fue un decir: -iputa! cagó todo. No solamente la parte política, cierto, que el movimiento político se detenía y de ahí un gran retroceso para todo, sino también a nosotros en lo personal nos tocó desde el punto de vista del cine, que estábamos por iniciar una experiencia cinéfila, en la cual, de alguna manera, nosotros íbamos a firmar dentro de una corriente del cine dentro de un experiencia que era la de Raúl Ruiz. Por lo tanto íbamos a iniciar una cosa que ambos queríamos hacer que era ficción.

Como eso se interrumpió, a mí me metieron preso, estuve cien días preso. Hubo ahí un lapsus, una interrupción bastante clara a nivel físico.

\section{¿Tú estabas militando en esa época?}

Sí, en el MAPU, éramos unos pocos. Ahí estaba la Chica Mesa, la María Eugenia, yo e Ignacio, éramos del MAPU, éramos como una célula. Y por eso me metieron preso porque cachaban que había una célula y trataron de seguir a través mío el hilo de todo. Menos mal que se quedó en mí no más.

La cosa es que yo, en el año 1974 volví a clases y dije voy a terminar la carrera, porque estaba en cuarto año y nos hicimos yunta con Cristian Sánchez. Entonces, dijimos: hagamos una cosa, juntémonos a hacer la película de egreso, juntos. Habíamos tenido una experiencia previa que había sido Esperando a Godoy, donde había estado él y Rodrigo Gonzalez. Habíamos sido los tres codirectores. Ahora ya no estaba Rodrigo, entonces, nos juntamos y dijimos: hagamos una película. $Y$ eso fue Vidas paralelas (1975). Para mí Vidas paralelas fue la película que yo quería hacer de carácter social, esa era la onda. Por eso que ves la película y ves largos planos de secuencias, mucha conversación, ves un delirio bastante desenfrenado, no es una historia, no hay historia. Y todas esas cosas: hacer películas sin historias, ficción.

\section{¿Fue el año 1974?}

La película salió el 1975, la filmamos en 1974. Se estrenó acá en Chile, la estrenó Cristian porque yo en septiembre me fui a Canadá.

\section{Eso quería preguntarte, ¿ahí tú fuiste por beca, por tu cuenta,} por exilio?

Me fui por el momento político, estaba chato. Ya no creía que podía hacer nada más en Chile. Estaba soltero y dije bueno, Io hago ahora o no lo hago nunca. Y me fui.

\section{¿Y ahí estudiaste allá?}

No, no estudié por una circunstancia: había estudiado ingeniería. Terminé ingeniería, hice el título de ingeniería y después empecé a estudiar cine. Pero después entré a los jesuitas, ahí estudié teología, luego filosofía. Y, después, entré a estudiar a la Escuela de Arte y Comunicación. Ya tenía treinta años y dije: no, ya he estudiado demasiado. No sabía que después iba a seguir estudiando, pero en ese momento me dije: voy a llegar a Canadá y no voy a estudiar nada en Canadá, voy a tratar de hacer cosas. En ese espíritu podría haber sacado un doctorado en $\mathrm{Ca}$ nadá perfectamente, pero no quise, me negué a estudiar. Tenía todas las posibilidades porque, a todo esto, yo era canadiense. Podía ingresar a cualquier universidad canadiense, tenía una buena base, en fin.

\section{¿Allá en qué estuviste trabajando?}

Allá estuve trabajando con la Marilú Mallet.

\section{Sales en la película El diario inconcluso (Marilú Mallet, 1983), te reconocí por la voz.}

Había entrado muy bien a la National Film Board. Y yo decía bueno, con la Marilú iba a poder hacer películas. De hecho, hicimos algo en común que fue una serie de seis capítulos en Radio TV Quebec, que era para la televisión, donde yo dirigí un capítulo.

\section{Esa es la serie del exilio, ¿no?}

Eran exiliados latinoamericanos. Yo hice una serie con los españoles que estaban allá, la Marilú lo hizo con los argentinos, con los portugueses...

\section{¿Documental o ficción?}

Eran documentales, eso fue como lo más consolidado que yo hice allá. Pero, trabajé también con otra gente en una cosa que se llamaba Maison culturel du Quebec-americalatina. Que era una casa de cultura de América Latina-Quebec donde estaba Gonzalo Millán y varios artistas más. Teníamos un grupo de gente que hacía temas ligados a lo cultural e hicimos un trabajo audiovisual, yo me conseguí recursos, pero era una cuestión menor. Leandro Urbina también estaba, quien era escritor.

\section{¿Era más bien vinculado a registros del momento, más institu-} cional?

Claro, estaba también Manuel Basoalto que había trabajado con Raúl Ruiz en Palomita blanca (1973/1990), que era uno de los personajes. Bueno, entre todos hicimos una casa cultural y estuvimos bastantes activos durante un año, año y medio.

Después, me pareció que iba a costar a entrar a este mundo. Me pareció que era un poco difícil. Había estado en España buscando posibilidades, estuve viviendo seis meses en España. Pero allá la industria del cine español era súper cerrada. Me daba cuenta por lo que me dijo Valeria, ni siquiera Raúl Ruiz pudo entrar en España, Valeria me decía que no hubo caso.

\section{¿Cómo llegaste a España?}

Porque tenía amigos allá.

\section{¿Tú viajaste allá? ¿No?}

Viví en España, estuve seis meses en Madrid.

\section{¿En qué año?}

En 1979. Me sirvió para conocer cine español, pero no hice nada.

\section{Imposible entrar. Y, después, de 1979 ¿volviste a Canadá?}

De ahí volví a Canadá. Y dije voy a volver a Chile, pero primero pasamos por Ecuador.

En paralelo seguías maquinando en tu mente igual, querías hacer películas en algún momento. 
Mira las opciones que yo tuve fue a través del video, por eso me conocen como un hombre del video. En los ochenta me decían que yo era un videísta. En parte por lo siguiente: porque el videísmo yo lo conocí en Canadá. En Canadá estaban súper desarrollados con el video. Yo iba a un lugar en que tenían cámaras para hacer videos, tenían editor de video y todo gratis, me inscribía, solicitaba la cámara y empecé a hacer videos así. Los videos que yo hacía eran con cinta de media pulgada de carrete abierto. Entonces me pasaban a cámara, yo filmaba todo e hice como 5 o 6 videos. Y me gustó mucho la libertad que tenía el video, o sea que no tenías que esperar una producción para hacer películas sino que accedías inmediatamente a hacer cosas.

Entonces con esa orientación yo postulé irme a Ecuador para hacer video en Ecuador. Y una corporación canadiense me financió: ándate a Ecuador, te irás como voluntario canadiense porque es la figura que tenemos, pero tú haces allá tus videos. Y fue lo que hice, me conseguí un lugar que era una ONG ecuatoriana, donde llegué con equipo, con cámaras, con betamax -que se llamaba en ese entonces-y empecé a hacer videos. Allá hice hartas cosas.

\section{¿Documentales?}

De hecho hice un documental que se llama Nanda Mañachi (1984) que yo siempre lo exhibo, porque ahí ya me entró el bichito del cine indígena. Eran indígenas de Otavalo en Ecuador que tenían un grupo musical que se llamaba Ñanda Mañachi. Y eran todos indígenas y cada uno trabajaba, uno hacía el coro y se juntaban en un grupo musical. Los seguí bastante tiempo. Los grabé en sus actividades diarias, todo esto en el volcán Imbabura y me pareció fascinante e hice esa película. Creo que fue el documental más logrado que yo había hecho hasta ese momento, con más recursos, estaba usando un aparato que se llamado U Matic de 3/4. Y ahí estuve dos años. Se terminó esa experiencia y dije: ya, me devuelvo a Chile; no quise volver a Canadá porque mi mamá me decía que ya, o sea podría haber vuelto, pero había una cuestión familiar.

\section{Estamos hablando del año 1982}

No, volvimos el 1985. En 1982 llegué a Ecuador.

\section{Regreso a Chile, el video}

Digamos que tú tenías noticias de que la cosa se estaba moviendo acá también.

Fue una cuestión familiar. Mi mujer, Isabel Duque, añoraba mucho a su familia. Los Duque son una familia muy unida, muy grande. Además hubiera sido entretenido volver a Chile en su momento. Dije, ya volvamos, además tengo un proyecto. ¿Cuál era ese proyecto? Hacer video en Chile, ese era mi proyecto.

\section{O sea hacer video en Chile ¿tenías equipo también?}

Tenía equipo, me conseguí un lugar en Chile que se llamada ECO. Estando en Ecuador llegó Fernando Ossandón y yo le dije: -Oye Fernando, quiero devolverme a Chile ¿tú me admitirías en tu grupo? Yo llevo los equipos, llevo todo y armamos una productora audiovisual. -Ya, me dijo, OK.

Me conseguí los recursos en Canadá, me dieron una plata, me compré los equipos y me volví a Chile. Mi idea era hacer una productora audiovisual por lo tanto tenía un proyecto, algo en que basarme. $Y$ empecé a hacer video, todos los años ochenta para mí fue la onda del video, pero en el fondo estaba haciendo documental.

Llegaste y empezaste a hacer video, pero ¿te topaste con otros grupos? Había grupos que hacían video comunitario, video arte y todos se juntaban en el grupo Franco-Chileno, según entiendo.

Lo que pasa es que quiero entrar a un asunto que se llama el formato documental ficcionado, por colocarle un nombre. El tipo de documental que yo me acostumbré a hacer fue en tensión con la ficción porque todos queríamos hacer ficción y no teníamos la posibilidad de hacer ficción, por lo menos yo. Cristian Sánchez se las arregló y lo hizo.

Mi horizonte fue hacer ficción siempre. Y, de alguna manera, yo aproveché el documental para ficcionar y entonces todo el mundo se asombra de eso. Me dice cómo descubriste eso. Pero yo no descubrí nada, simplemente fueron mis ganas de hacer ficción que me llevaron a hacer lo que estoy haciendo, en lo cual siempre que hay un elemento que no puedo documentar, lo ficcionizo. O sea, la ficción mía es completar el documental.

El documental sale como tal, entonces, eso empecé a hacer en ECO. Por ejemplo, si tú ves Caminito al cielo y Cuartito rosa, en ambos, yo hago actuar a los personajes. Porque llega un momento en que, por ejemplo en Caminito al cielo había un robo ¿cómo puedo documentar un robo? Y uno de los chicos me dijo: -Yo soy ladrón, o sea, sabían cómo robar. Y le dije: -Oye, mira hagamos una cosa, muéstrame cómo robas tú. Y lo filmé. Y sale este cabro chico -13 años-ahí en el parque forestal sacándole una gargantilla a una niña y eso es totalmente como él lo hacía; era la forma de ser ladrón.

Entonces, me di cuenta que el documental tenía una proyección que iba más allá de estrictamente el registro y tenía que ver con un documental expandido, por decirlo de alguna manera, que acerca muy bien con el documental que tiene documental.

Y podemos decir que estas dos, centralmente, Caminito al cielo y Cuartito rosa son las más representativas de este periodo y esa búsqueda en ese momento. $Y$ una pregunta rápida: la cosa del Franco-chileno de los encuentros ¿estabas cerca de eso o lejos?

No, yo no entré en eso. Yo era outsider de ahí.

\section{Pero igual estabas escribiendo, tienes un texto ahí.}

Sí, lo que pasa es que yo trabajé más bien con las productoras que hacían lo que se llamaba video alternativo donde estaba Góngora, Sale, Mondaca -que era una productora que se llaman Proceso.

Éramos como cinco productoras alternativas: El Análisis, Eliptus, ECO y Proceso. Ese era mi campo de acción, no era el videoarte nunca entré en el videoarte. Aunque hice clases de videoarte después en la Universidad Católica, pero nunca entré al videoarte como tal. No me sentía representado por el videoarte, me gustaba mucho. Pero, no sabía cómo hacerlo, no me salía. Yo tenía esta otra cosa entre documental y ficción que era mi forma de ser propia, y me orienté hacia allá. Entonces, Caminito al cielo, Cuartito rosa, Nostalgias del Far West, todos estos documentales los hago en ECO.

Y estaba esta onda media alternativa que hacíamos reuniones latinoamericanas. Fui a Cochabamba, a Argentina, donde se reunían todos los grandes videístas de América Latina en un gran 
movimiento, fue una cuestión bien humanitaria que duró como cuatro o cinco años.

Perfecto, cuéntame más del colectivo del Cabo Astica ¿qué pasó? Eso fue con los trabajos con Jorge Teillier, también hay uno sobre Astica y hay otro más, un tercero.

Bueno, era un grupo de amigos que nos encontramos en ECO: Ricardo Carrasco, mi cuñado Gonzalo Duque, Vicente Parrini. Pero, era un grupo muy joven para mí, ellos venían saliendo de la universidad y yo ya era un gallo de cuarenta años. Pero igual nos juntamos en ECO porque estaba el aparato productivo para hacer películas.

Entonces, Parrini, que era el periodista, era un tipo muy loco. A él se le ocurrió primero hacer lo del Cabo Astica ${ }^{1}$ en Valparaíso y, después, hacer lo de Jorge Tellier en Lautaro. Eran contactos que él tenía, pero nadie sabía hacer video. Yo era el experto ahí, el que podía hacer todas esas cosas. Entonces, todos querían video al mismo tiempo, todos querían meter mano; yo eso lo encontraba fatal como le pasó a Raúl Ruiz cuando intentó hacer esa experiencia colectiva que fracasó. Es muy difícil hacer algo colectivo de esa manera, entonces, con mi paciencia me coloqué en una situación muy receptiva para ver lo que querían hacer, pero si tú ves tanto el Cabo Astica y Nostalgias del Farwest (1987) tienen ficción. Yo ahí estaba en pugna con Parrini porque como periodista quería hacer entrevistas, pero yo le decía no Parrini hagamos una película, él insistía mucho en eso. Al final me empezaron a tomar en cuenta y llevamos la cosa a la ficcionalización. Entonces ya en el Cabo Astica aparece Astica ficcionado.

Después con Tellier ya caemos de lleno en la ficción a tal punto que yo hice el guión no más. Escribí el guión ficcionado leyendo la poesía de Tellier. Le dije a Parrini: -Tu eres periodista hagamos entre los dos el guion. Por ejemplo toda la parte que transcurre en el tren es ficción y está hecho por guión, aplicamos guión estrictamente para hacer esa parte. Cuando llegamos a Lautaro ya la anarquía era total, partían para allá para acá. Pero el esqueleto de ficción se mantuvo. Pasamos a ficcionar, que la idea fuese de Tellier, lo que él quería como hálito poético. En gran parte tú ves que es eso. Y después Ricardo Carrasco tomó mucho una idea y él hace una cosa bastante genial, a mi modo de ver, que lo hace en Cabildo donde estaba viviendo Tellier. Fue como una parte que hicimos posterior de Lautaro, lo terminamos en Cabildo y él hace la cosa donde está una empleada doméstica tirándole un paño al sillón y que quedó una cuestión espectacular. O sea a mí me gustó mucho eso. Y estas cosas yo las sé sin darme cuenta, estoy con el tiempo dándome cuenta que venía de una línea que venía ya de Ñanda Mañachi que continua después con la experiencia del Cabo Astica, con Cuartito Rosa y se fue constituyendo una cosa, en la cual nunca abandono la ficción para hacer documental.

\section{Lo formativo e investigativo}

Tengo otra pregunta que me interesa mucho. En paralelo a esto tú hacías clases. Desde que te conozco estás en esa búsqueda de formalización teórica ¿En estos periodos también estabas escribiendo?

En Ecuador escribí una novela. Estaba en esa onda, quería hacer novela. Y la escribí y publicaron acá en Chile en la Editorial Ornitorrinco. Es la única novela que he hecho en realidad. Y eso te habla que yo quería ficcionar y no podía, entonces, me aboqué a la novela. Yo empecé a teorizar cuando empecé a hacer clases en la UNIAC.

\section{¿Eso en qué año? ¿Finales de los 80 también o en la década de} los 90?

Fue en los años 90, 1992-1993. A mí me encargaron hacer un curso de cine y de guión en la UNIAC. Ahí empecé a leer como loco. Ahí entré con Deleuze, que sé yo, y con mucha gente más. Me di cuenta que era lo que a mí me gustaba. Empecé a leer como loco, me pasé cinco años leyendo todo lo que podía encontrar teórico acá en Chile.

Entré a la ARCIS en ese momento y ahí empecé a escribir porque las clases las escribía, escribía todas las clases, y después de un tiempo me encontré con un alto de cosas que había escrito, que tenía que ver con la teoría del cine con la imagen y todo eso lo fui desarrollando en ese momento. Yo creo que de a poco me fui entusiasmando con la teoría. O sea, no fue algo deliberado, que yo diga ya voy a estudiar un doctorado y de ahí me voy a dedicar a la crítica. Todo lo contrario, fue que la parte académica me empezó cada vez más a tomar y empecé lentamente a dejar la parte de producción de cine, no del todo, porque igual hice varios documentales entre medio.

Pero la parte académica fue para mí un gran descubrimiento, principalmente, porque en ese tiempo estábamos descubriendo tipos notables como el mismo Deleuze que eran capaces de removerte todo lo que uno creía en ese momento.

\section{Tu primer libro propiamente fue El cine como medio expresivo} que sacaste por la UV.

Ese lo hice con los apuntes.

Digamos que es un registro de un recorrido de una teoría más estructuralista, podríamos decir ¿cierto? Y de ahí una recepción en el segundo libro que hiciste de las imágenes, un posestructuralismo (Poética de las imágenes de cine).

Toda la parte semiológica nuestra fue en la escuela. En la escuela había unos semiólogos brasileños que habían huido de la dictadura, Luis Felipe Rivero, eran semiólogos puros, fuertemente semiólogos. De hecho la tesis que hice con Aldo Francia tiene mucho de semiología. Pero, eso lo abandoné porque lo encontré muy limitado, muy estructuralista. Y, para mí, esta cuestión más filosófica de ver el cine, la convergencia entre cine y filosofía, fue lo que me empezó a interesar. Parte con André Bazin, que es toda una cosa bastante existencialista del cine que a mí me gusta mucho. Pero, después entrar con Deleuze fue como superar un poco eso y ahí empecé a digamos a otro más filosófico. Yo creo que eso ha sido lo que he trabajado los últimos veinte años.

Santiago de Chile, abril 2019

1. De las armas y de las letras (Colectivo Cabo Astica, 1987). 